\title{
Southern Pine Coneworm, Dioryctria amatella (Hulst) (Insecta: Lepidoptera: Pyralidae ${ }^{1}$
}

James R. Meeker ${ }^{2}$

\section{Introduction}

The southern pine coneworm, Dioryctria amatella (Hulst), also commonly referred to as a pitch moth, is consistently one of the most damaging insect pests of pine seed orchard crops throughout the southeastern United States (Ebel et al. 1980). Less well-recognized is that this widespread and frequently occurring insect also attacks a variety of other parts of pines (Pinus spp.) besides cones. Caterpillars can be found feeding on and in buds, male and female flowers, shoots, branches and stems of all ages and sizes, as well as in conelets (i.e., first-year cones) and second- year cones (Ebel 1965, Ebel et al. 1980, Goolsby et al. 1972).

The prevalence and variety of $D$. amatella infestations on forest and shade trees pines throughout the state periodically generates concern over the nature and impact of its injuries. The most noticeable symptom of infestations is large external masses of pitch exuding from the feeding sites of caterpillars, hence the name "pitch moth." Reddish-brown frass may also be evident at feeding sites and is often mixed with resin. Pitch masses caused by $D$. amatella

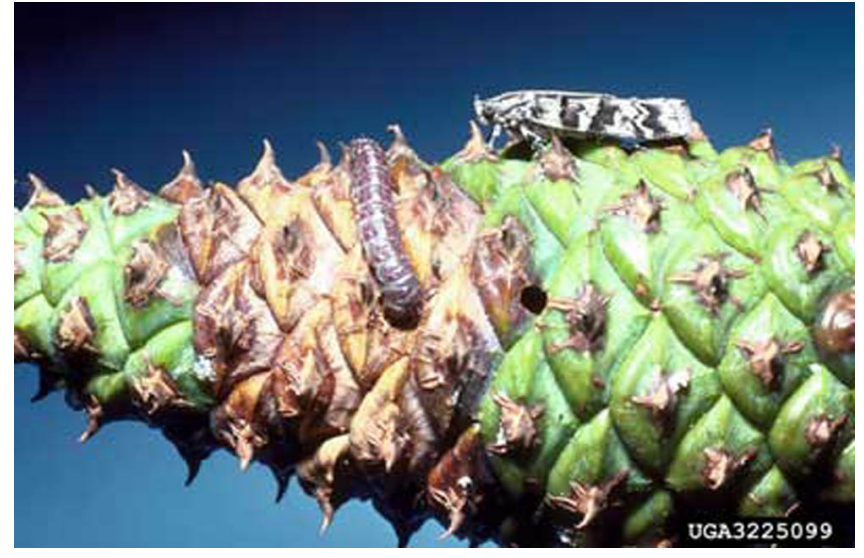

Figure 1. Adult and larvae of the southern pine coneworm, Dioryctria amatella (Hulst), on loblolly pine cone. Credits: Photograph by: R. Scott Cameron, International Paper, www.forestryimages.org

may resemble those of the black turpentine beetle (BTB), Dendroctonus terebrans (Oliv.); however, the coneworm pitch masses are usually larger, more irregularly shaped and flow for months. BTB pitch masses are typically less than $25 \mathrm{~mm}$ in diameter, have an obvious entrance hole, solidify in weeks, and are concentrated on the lower bole of large trees (Barnard and Dixon 1983, Goolsby et al. 1972).

1. This document is EENY-325 (originally published as DPI Entomology Circular 393), one of a series of Featured Creatures from the Entomology and Nematology Department, Florida Cooperative Extension Service, Institute of Food and Agricultural Sciences, University of Florida. Published: May 2004. This document is also available on Featured Creatures Website at http://creatures.ifas.ufl.edu. Please visit the EDIS Website at http://edis.ifas.ufl.edu. Additional information on these organisms, including many color photographs, is available at the Entomology and Nematology Department website at http://entnemdept.ifas.ufl.edu/.

2. James R. Meeker, Florida Department of Agriculture and Consumer Services, Division of Forestry, Gainesville, FL.

The Institute of Food and Agricultural Sciences (IFAS) is an Equal Employment Opportunity - Affirmative Action Employer authorized to provide research, educational information and other services only to individuals and institutions that function without regard to race, creed, color, religion, age, disability, sex, sexual orientation, marital status, national origin, political opinions or affiliations. For information on obtaining other extension publications, contact your county Cooperative Extension Service office. Florida Cooperative Extension Service / Institute of Food and Agricultural Sciences / University of Florida / Larry R. Arrington, Interim Dean 
In addition to reproductive structures, susceptible host material includes: trees under stress, mechanically injured stems or branches, elongating shoots of long leaf (P. palustris Mill.) and slash pine ( $P$. elliottii Englem.) during the spring, graft and branch unions, conelets infected with the southern cone rust fungus (Cronartium strobilinum (Arth.) Hedge \& Hahn) and especially galls caused by the fusiform rust fungus (Cronartium quercuum (Berk.) Miyabe ex Shirai f. sp. fusiforme) (Barnard and Dixon 1983, Ebel et al. 1981, Goolsby et al. 1972). Other than the potentially significant losses that can occur in seed orchards due to the destruction of flowers, conelets and cones, damage is rarely severe or lethal to trees. The girdling effect of caterpillar feeding, however, can cause dieback of branches, terminals and tree tops, and additional weakening of previously damaged sterns (Barnard and Dixon 1983). Feeding injuries also serve as infection courts for the pitch canker fungus, Fusarium subglutinans (Wollenw .and Reinking) Nelson, Toussoun and Aarasas (Foltz and Blakeslee 1989).

\section{Distribution}

D. amatella occurs throughout Florida and likely can be found wherever its pine hosts are growing. The natural range of the insect extends across the southeastern U.S., from Maryland south to Florida and west into Texas (Ebel et al. 1980).

\section{Identification}

D. amatella is one of six species of pine coneworrns found in Florida. Others include: the blister coneworrn (D. clarioralis (Walker)), the webbing coneworrn (D. disclusa Heinrich), the south coastal coneworrn (D. ebeli Mutuura \& Monroe), the loblolly pine coneworrn (D. merkeli Mutuura \& Monroe), and the lesser loblolly pine coneworrn ( $D$. taedivorella Neunzig \& Leidy) (Ebel et al. 1980). A seventh species, the bald cypress coneworrn $(D$. pygmaeella Ragonot), is only known on junipers and cypress. D. amatella can be distinguished from these other species by the distinct characteristics of adults and larvae, and often via differences in damage and biology.

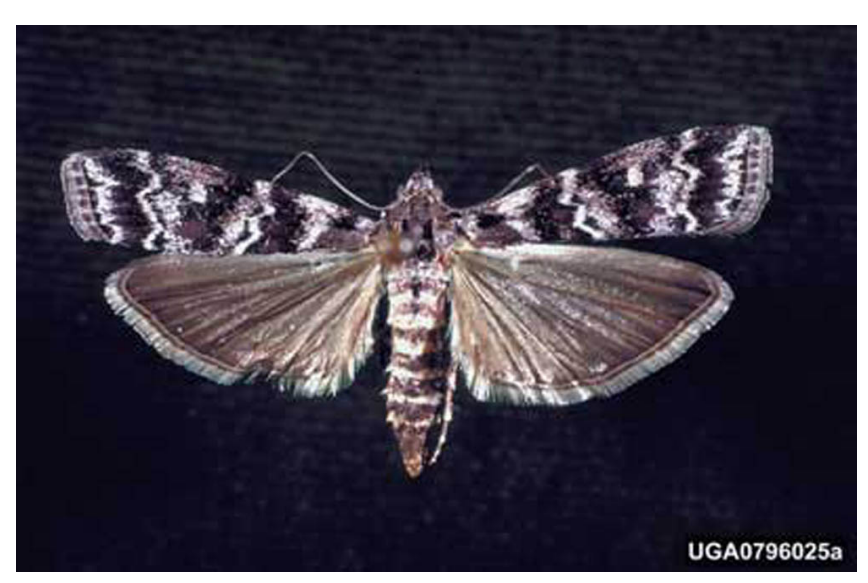

Figure 2. Adult southern pine coneworm, Dioryctria amatella (Hulst). Credits: Photograph by: R. Scott Cameron, International Paper, www.forestryimages.org

Adult moths of $D$. amatella have a wingspan of 27 to $32 \mathrm{~mm}$, with dark grey, to brown, to nearly black forewings boldly patterned with multiple contrasting white patches and zig-zag crossbands. The hindwings are nearly uniformly light grey to tan in color. Larvae range from $1.5 \mathrm{~mm}$ upon hatching, to ca. $25 \mathrm{~mm}$ at maturity. When young, their bodies are nearly white with seven longitudinal stripes and a brown head. Older larvae are colored a dark reddish to purplish brown above and are a paler whitish green on the underside. Abdominal segments exhibit obvious beadlike patterns of small black pits and dark elevated setal bases (Ebel et al. 1980).

\section{Biology}

In Florida, the southern pine coneworm produces from one to four generations per year, depending on whether larval diapause occurs during the spring, early summer, or at all. The resulting abundant overlap of life stages among generations typically yields varying degrees of adult moth activity from early April through early November in North Florida (Merkel and Fatzinger 1971). The insect overwinters predominantly as early instar larvae, at the base of persistent cones, under bud scales and in fusiform galls on branches and sterns. As larvae become active in January, they may continue to feed in overwintering sites or often migrate to feed on developing male and female flowers and vegetative buds. Following flower and bud feeding, larvae usually migrate a second time, infesting expanding shoots or young second-year cones during early spring. Once in shoots, larvae may undergo diapause, 


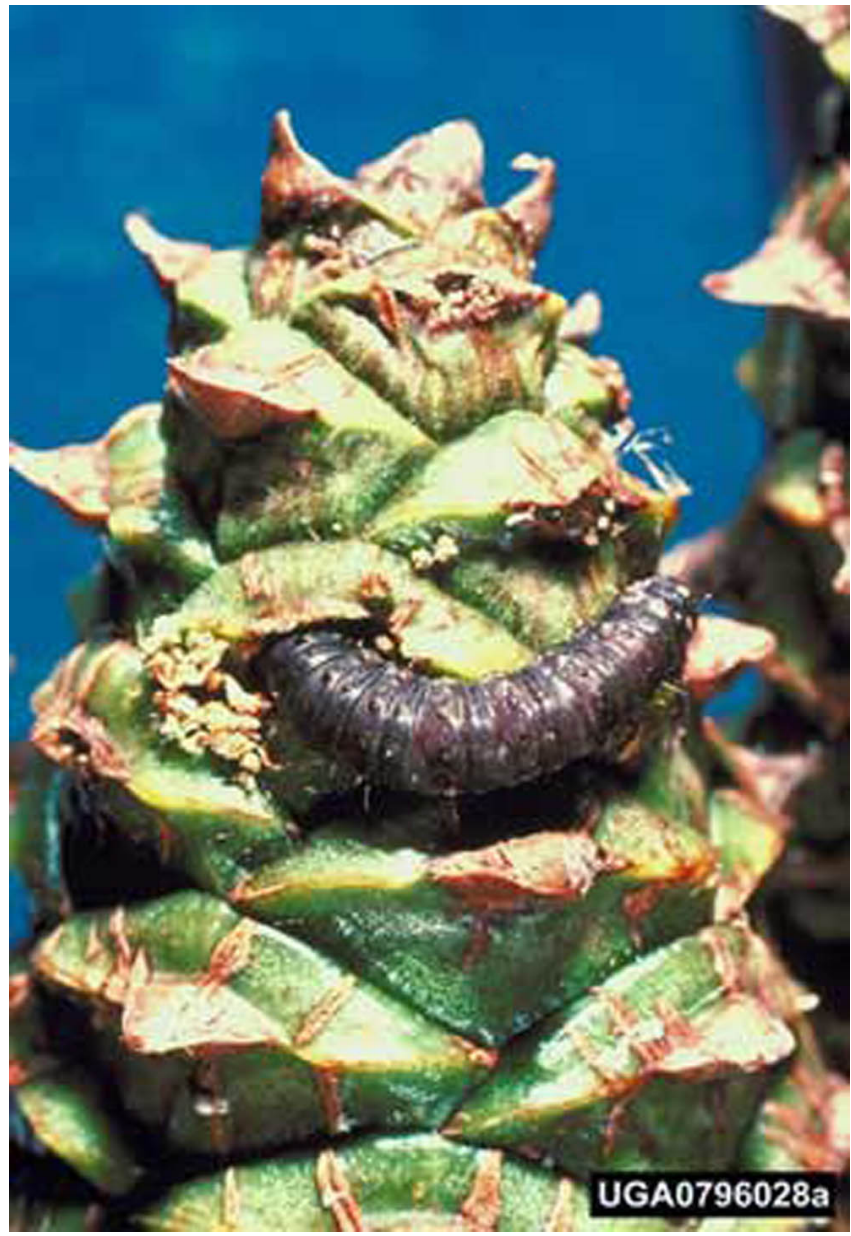

Figure 3. Mature larva of the southern pine coneworm, Dioryctria amatella (Hulst). Credits: Photograph by: Harry O. Yates III, USDA Forest Service, www.forestryimages.org

complete their development or migrate again to young second-year cones. When larvae eventually pupate, D. amatella is the only pine coneworm in the South that does so within infested material (Ebel 1965).

In April and May, the next generation of caterpillars readily infests conelets infected with southern cone rust, as well as healthy second-year cones. These larvae, as well those of subsequent generations, also may migrate from infested to uninfested cones before pupating. Later generations continue to infest second-year cones from summer through fall (Ebel 1965). This relatively complex cycle is depicted in figure below.

\section{Host Plants}

All species of Pinus native to the state are utilized as hosts by $D$. amatella. This list includes: loblolly ( $P$. taeda L.), longleaf, pond (P. serotina Michx.), sand (P. clausa (Chapm. ex Englem.)), shortleaf ( $P$. echinata Mill.), slash and spruce $(P$. glabra Walt.) pines. Virginia pine, $P$. virginiana Mill., which is sometimes ill advisedly grown in Florida for Christmas trees, is often infested by $D$. amatella. Eastern white pine, $P$. strobus L., is the only Pinus spp. which occurs in Florida that is not a suitable host (Ebel et al. 1980). Within slash pine, and probably other host species, individual trees exhibit pronounced differences in their inherent degree of susceptibility or resistance to $D$. amatella infestations (Merkel et al. 1965).

\section{Damage}

In cones, larval feeding causes damage ranging from evident tunnels to wholly excavated cavities within, resulting in partial to complete seed loss of infested individuals (Ebel et al. 1980). Other forms of damage are pictured, in part, in images below. Foltz and Blakeslee (1989) found that the abundance of $D$. amatella infestations in young, experimental slash pine plantations increased with the intensity of applied cultural practices (e.g., fertilization, competition control, and irrigation); and in the late 1990s, a four year-old long leaf plantation on a scalped agricultural field in Lafayette County exhibited an estimated 5\% terminal dieback due to shoot infestations. The unknown ramifications of trends towards more intensive, high-yield management of many loblolly, slash and long leaf plantations may alter the pest status and management considerations for D. amatella in the future.

\section{Management}

Various insecticides are currently registered for and routinely used in intensively managed pine seed orchards to successfully prevent and/or minimize seed losses due to coneworms. The presence and timing of $D$. amatella and most other coneworms can be determined by using commercially available pheromone lures and traps. Without the use of insecticides in an integrated pest management system, 


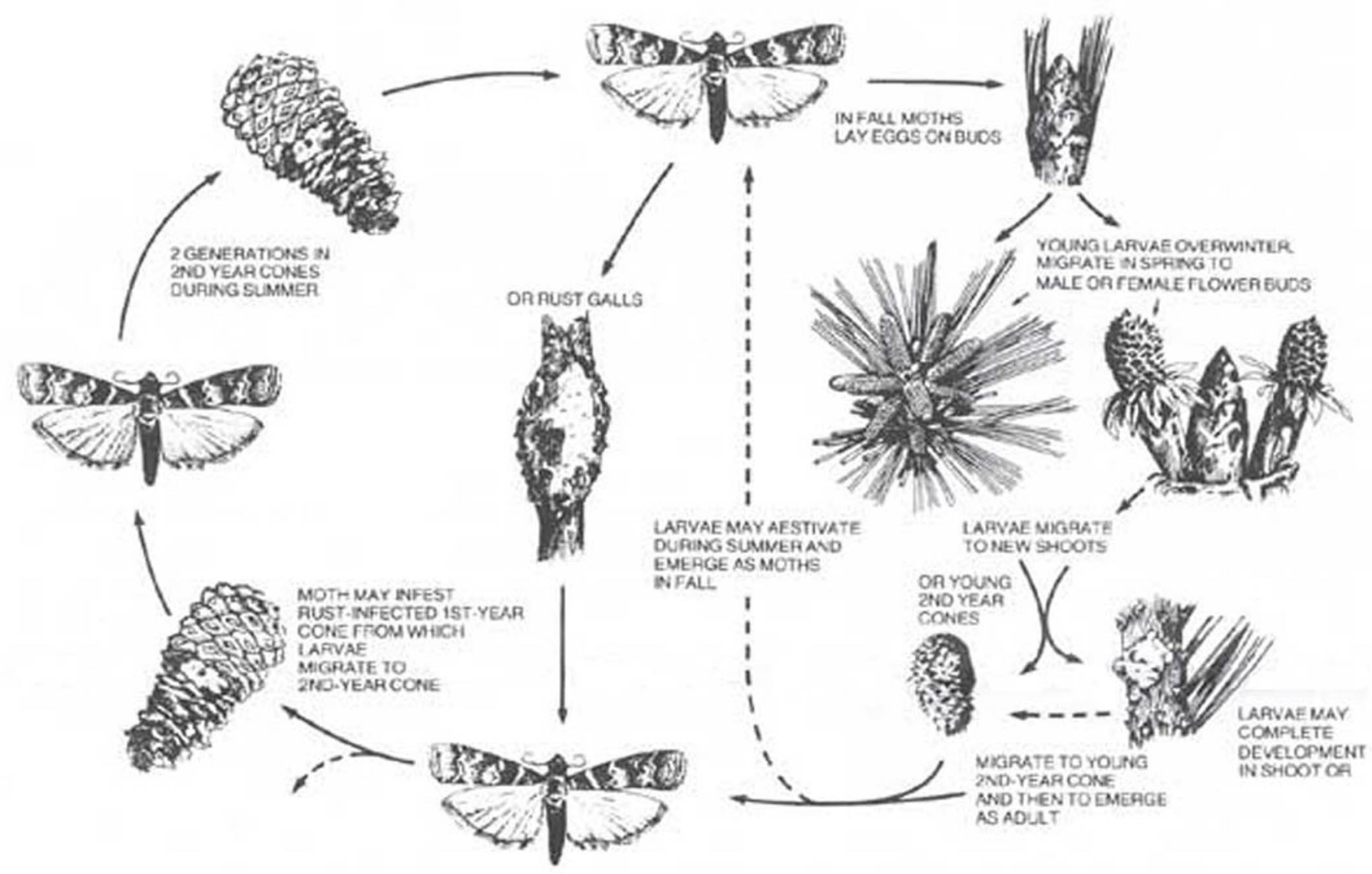

Figure 4. Diagram of major aspects of comple life cycle of the southern pine coneworm, Dioryctria amatella (Hulst) On loblolly pine, the cones-to-gall cycle (left) is typical; in slash and longleaf pines, a variety of additional host plants parts may be fed upon in the spring (from Hedlin et al. 1981). Credits: Hedlin et al. 1981

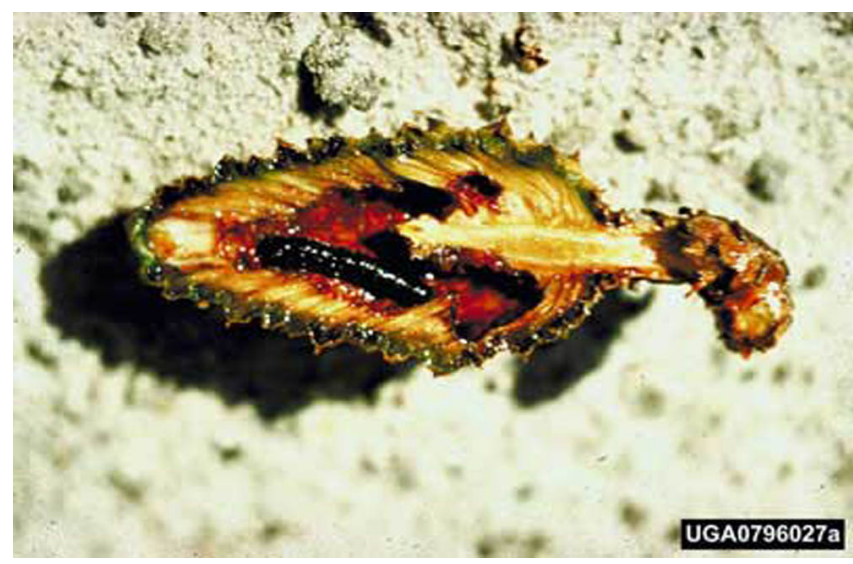

Figure 5. Mature larva of the southern pine coneworm, Dioryctria amatella (Hulst), feeding in second year slash pine cone. Credits: Photograph by: Bernard H. Ebel, USDA Forest Service, www.forestryimages.org

seed orchards in North Florida could expect to annually lose between 20 to $40 \%$ of their crop to coneworms (Goolsby et al. 1972). In most conventional forestry and shade tree settings, there is

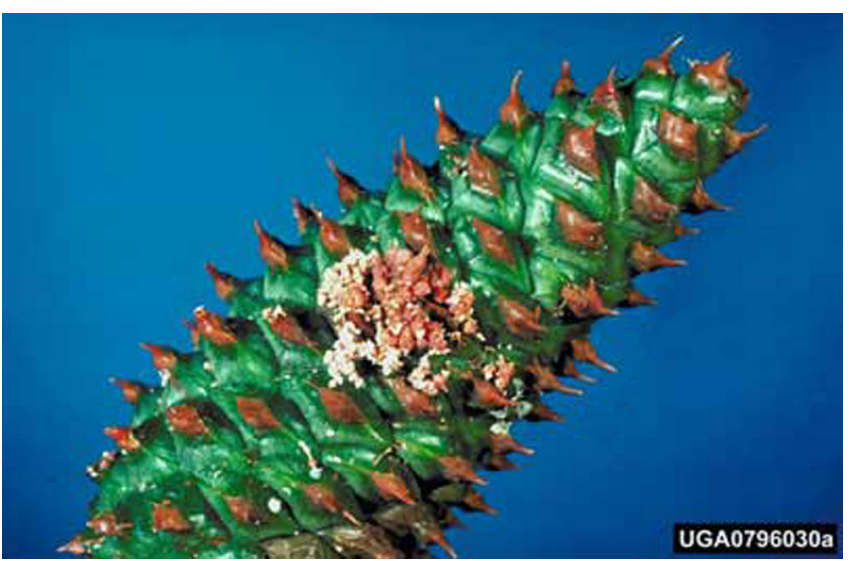

Figure 6. Damage to a mature pine cone, caused by feeding of the southern pine coneworm, Dioryctria amatella (Hulst). Credits: Photograph by: Larry R. Barber, USDA Forest Service, www.forestryimages.org

little practical potential for insecticide use due to: the random nature of attacks, the inability of most insecticides to control existing infestations, the 


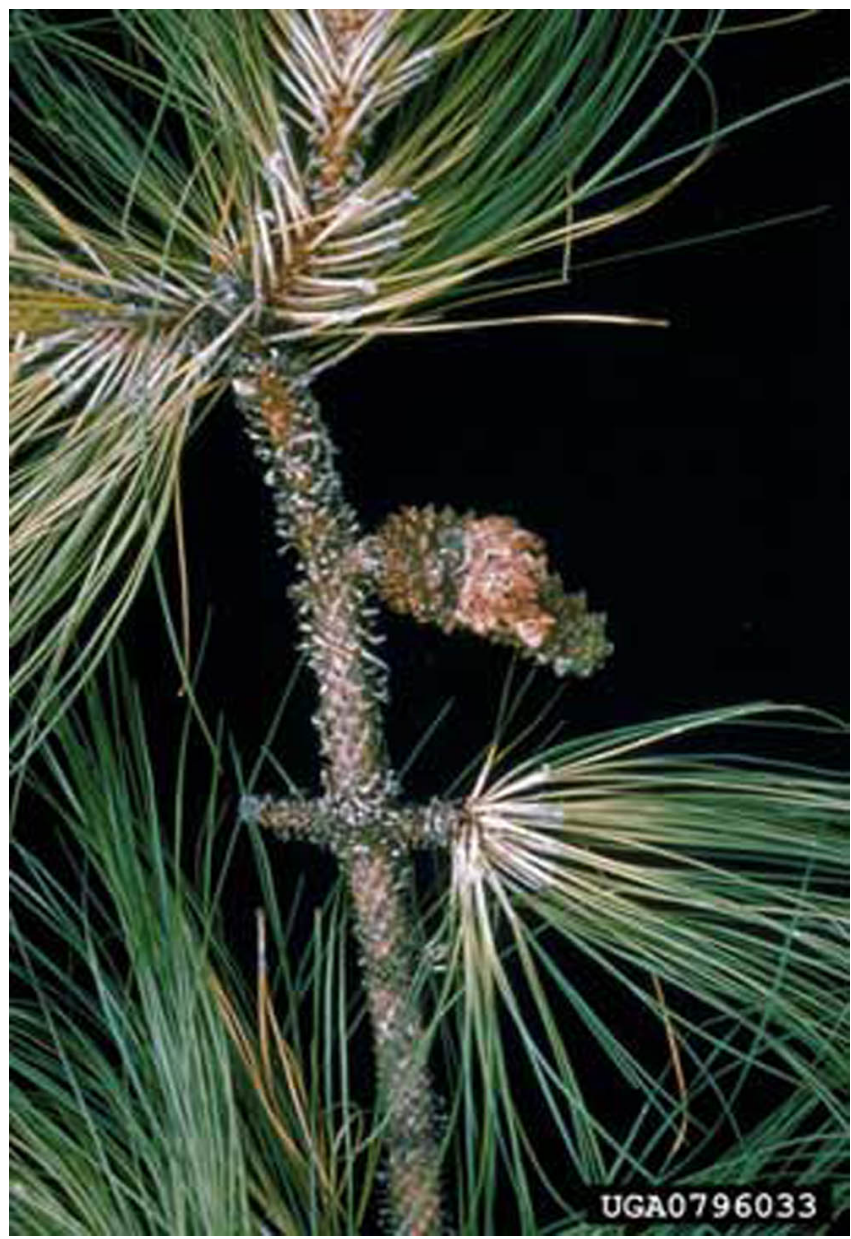

Figure 7. Damage to an immature pine cone, caused by feeding of the southern pine coneworm, Dioryctria amatella (Hulst). Credits: Photograph by: Harry O. Yates III, USDA Forest Service, www.forestryimages.org

relatively limited impact of damage, and the high cost-benefit ratio.

Insect Management Guide for Commercial Forest Trees (http://edis.ifas.ufl.edu/IG058)

Insect Management Guide for Pine Seed Orchards (http://edis.ifas.ufl.edu/IG057)

Recommended management strategies include promoting and maintaining tree health and vigor, and removal and destruction of seriously infested and/or rust infected stems and branches. Avoid mechanical injuries to branches and stems because of $D$. amatella's attraction to volatiles emanating from wounds (Hanula et al. 1985). In Florida, eight species of Hymenoptera (three braconids, three ichneumonids and two eulophids) and two species of tachinid flies have been reported as natural enemies of D. amatella larvae or pupae. It appears, however,

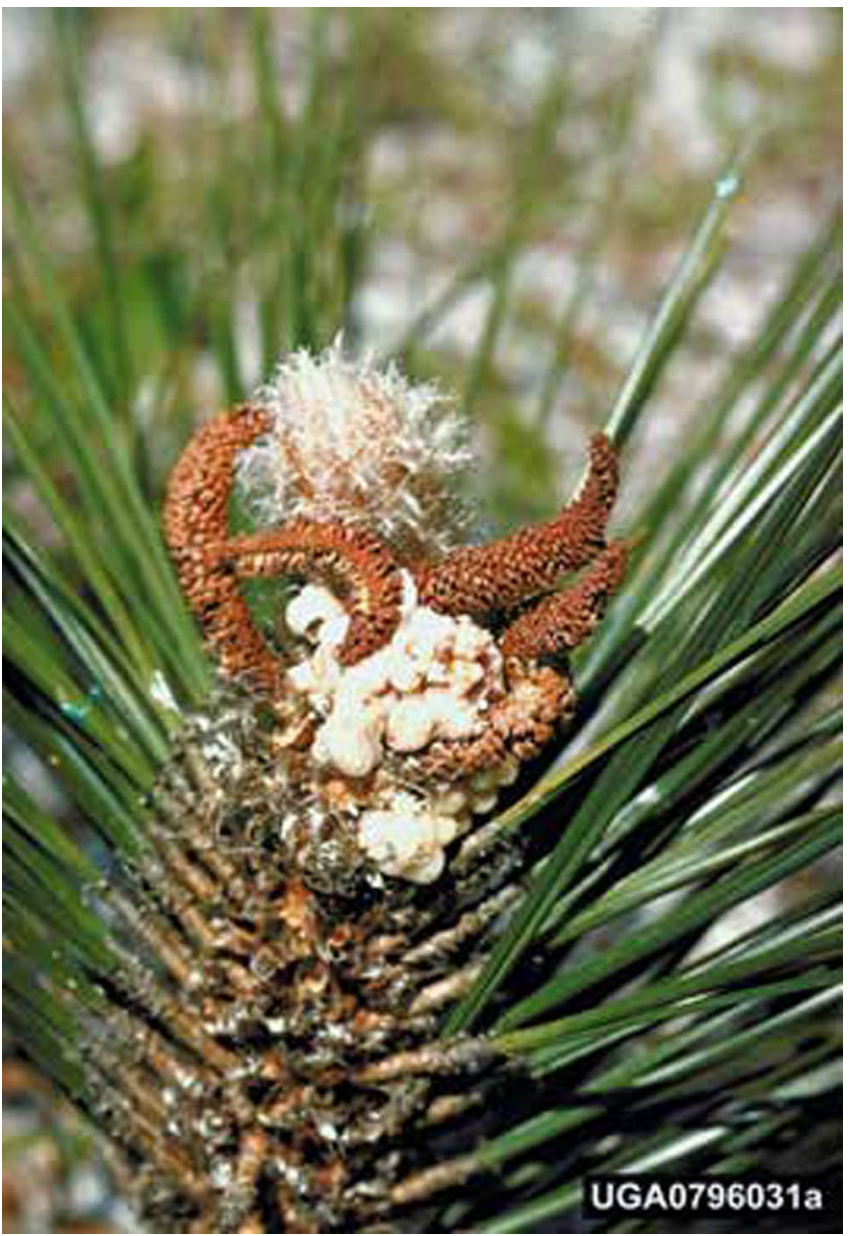

Figure 8. Bud and shoot damage following male flower injuries on longleaf pine due to feeding by larvae of the southern pine coneworm, Dioryctria amatella (Hulst). Credits: Photograph by: Bernard H. Ebel, USDA Forest Service, www.forestryimages.org

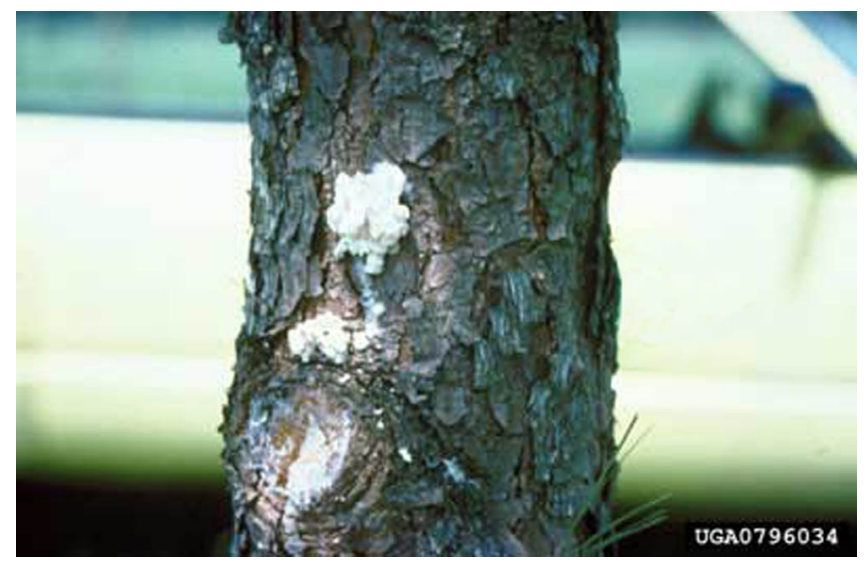

Figure 9. Attack on pruning wounds in a loblolly seed orchard by larvae of the southern pine coneworm, Dioryctria amatella (Hulst). Credits: Photograph by: Andrew J. Boone, South Carolina Forestry Commission, www.forestryimages.org 
that the combined impact of these parasitoids is not enough to substantially reduce or control populations of this coneworm (Belmont and Habeck 1983, Ebel 1965).

\section{Selected References}

Barnard EL, Dixon WN. 1993. Insects and Diseases: Important Problems of Florida's Forest and Shade Tree Resources. Florida Department of Agriculture \& Consumer Services, Division of Forestry. Bulletin No. 196-A. 120 p.

Belmont RA, Habeck DH. 1983. Parasitoids of Dioryctria spp. (Pyralidae: Lepidoptera) coneworms in slash pine seed production areas of north Florida. Florida Entomologist 66: 399-407.

Ebel BE. 1965. The Dioryctria coneworms of North Florida pines (Lepidoptera: Phycitidae). Annals of the Entomological Society of America 58: 623-630.

Ebel BH, Flavell TH, Drake LE, Yates III HO, DeBarr GL. 1980. Seed and Cone Insects of Southern Pines. U.S. Department of Agriculture, Forest Service, Southeastern Forest Experiment Station and Southeastern Area State and Private Forestry. General Technical Report SE-8. 43 p.

Foltz JL, Blakeslee GM. 1989. Insects associated with the intensive culture of Pinus ellottii and $P$. taeda in Florida. pp. 19-26. In Alfaro RI, Glover SG. (eds.). Insects Affecting Reforestation: Biology and Damage. Forestry Canada. Victoria, British Columbia, Canada.

Goolsby RP, Ruehle JL, Yates III HO. 1972. Insects and Diseases of Seed Orchards in the South. Georgia Forest Research Council. Report No. 28. 25 p.

Hanula JL, Berisford CW, DeBarr GL. 1985. Monoterpene oviposition stimulants of Dioryctria amatella in volatiles from fusiform rust galls and second-year loblolly pine cones. Journal of Chemical Ecology 11: 943-952.

Hedlin AF, Yates III HO, Cibrián Tovar D, Ebel BH, Koerber TW, Merkel EP. 1981. Cone and Seed Insects of North American Conifers. Canadian
Forestry Service, U.S. Forest Service, Secretaria de Agricultura y Recursos Hidr ulicos, Mexico. 122 p.

Merkel EP, Fatzinger CW. 1971. Periodic abundance of pine cone-infesting Lepidoptera in black light traps and sleeve cages in North Florida. Florida Entomologist 54: 53-61.

Merkel EP, Squillace AE, Bangston GW. 1965. Evidence of inherent resistance to Dioryctria infestation in slash pine. pp. 96-99. In (eds) Proceedings of the Eighth Annual Southern Forest Tree Improvement Conference, Savannah, Georgia. 